\title{
Nurse educators' perceptions of OSCE as a clinical evaluation method
}

\author{
MM Chabeli, Nursing Science Department, RAU
}

\begin{abstract}
The South African Qualifications Authority, and the South African Nursing Council are in pursuit of quality nursing education to enable the learners to practise as independent and autonomous practitioners. The educational programme should focus on the facilitation of critical and reflective thinking skills that will help the learner to make rational decisions and solve problems. A way of achieving this level of functioning is the use of assessment and evaluation methods that measure the learners' clinical competence holistically.
\end{abstract}

This article is focused on the perceptions of twenty nurse educators, purposively selected from three Nursing Colleges affiliated to a university in Gauteng, regarding the use of OSCE (Objective Structured Clinical Examination) as a clinical evaluation method within a qualitative and descriptive research strategy. Three focus group interviews were conducted in different sessions. A descriptive content analysis was used. Trustworthiness was ensured by using Lincoln and Guba's model (1985). The results revealed both positive and negative aspects of OSCE as a clinical evaluation method with regard to: administrative aspects; evaluators; learners; procedures/instruments and evaluation. The conclusion drawn from the related findings is that OSCE does not measure the learners' clinical competence holistically. It is therefore recommended that the identified negative perception be taken as challenges faced by nurse educators and that the positive aspects be strengthened. One way of meeting these recommendations is the use of varied alternative methods for clinical assessment and evaluation that focus on the holistic measurement of the learners' clinical competence.

\section{Uittreksel}

Die Suid-Afrikaanse Kwalifikasie Owerheid sowel as die
Suid-Afrikaanse Raad op Verpleging strewe daarna om gehalte verpleegonderwys daar te stel ten einde leerders instaat te stel om as onafhanklike en outonome praktisyns te praktiseer. Om die rede behoort opvoedkundige programme op die fasilitering van kritiese en reflektiewe denke te fokus wat die leerder behulpsaam gaan wees om rasionele besluite te neem asook om probleme op te los. Een sodanige wyse waardeur hierdie vlak van funksionering bereik kan word is deur die aanwending van assessering- en evalueringsmetodes wat die leerder se vaardigheid op ' $n$ holistiese wyse meet.

Hierdie artikel fokus op verpleegopvoedkundiges se persepsies van die aanwending van " $\mathrm{OGKE}$ as " $\mathrm{n}$ kliniese evalueringsmetode. Twintig verpleegopvoedkundiges is op ' $n$ doelgerigte wyse geselekteer vanuit drie verpleegkolleges wat aan ' $n$ Universiteit in Gauteng geaffilieer is. " $n$ Kwalitatiewe en beskrywende strategie is aangewend. Drie fokusgroeponderhoude is tydens drie verskillende sessies uitgevoer. 'n Beskrywende metode van inhoudsanalise is aangewend. Vertrouenswaardigheid is verseker deur die aanwending van Lincoln en Guba se model (1985). Die bevindinge reflekteer beide positiewe en negatiewe aspekte van die OGKE met betrekking tot die Administrasie, Evalueerders, Leerders, Prosedure/Instrument en Evaluering. Die gevolgtrekking waartoe daar vanuit die bevindinge gekom is, is dat die OGKE nie die leerder se kliniese vaardighede op ' $n$ holistiese wyse meet nie. Om dié rede word daar aanbeveel dat die persepsies wat as negatief geïdentifiseer is as " $n$ uitdaging deur verpleegopvoedkundiges gesien word en dat die positiewe aspekte versterk word. Een sodanige wyse waarop hierdie aanbeveling bereik kan word, is deur die aanwending van ' $n$ verskeidenheid alternatiewe metodes van kliniese assessering en evaluering wat op ' $n$ holistiese meting van 'n leerder se kliniese vaardigheid fokus.

\section{Introduction}

Clinical nursing education lies at the heart of a nurse's professional practice and therefore a learner's competency in clinical nursing education is an important component of comprehensive programmes leading to registration as a professional nurse with the South African Nursing Council. It has been established beyond doubt that assessment and evaluation greatly influence learning and define the de facto curriculum (Ramsden, 1992). Much as the assessment and evaluation of a learner's clinical competency are of great importance, they are, however, unfortunately complex and present difficulties since there is a demand for accountability in the profession.

To reiterate this point, Halloway $(2000: 2)$ asserts that beyond the profession there is certainly a demand in many countries for greater accountability. Government and employment authorities have used legislative force to require better education and training standards. Employers complain of poor skills among graduates and hold educational institutions responsible for this. The move towards competency-based learning is further evidence of efforts within and beyond the profession to identify and find a means to improve teaching and learning. 
South Africa is facing similar problems of equipping the learners with competencies that will help to make them active and valuable participants in creating a better country and a better future for all through education (Van der Horst \& McDonald, 1997:5). An effective educational system is realised through effective assessment and evaluation methods as stated by Astin (in Gravett, 2000), “An institution's assessment and evaluation practices are a reflection of its values".

Outcomes-based education system, Van der Horst \& McDonald (1997:169) require learners to demonstrate what they really know, are able to do and appreciate. This shift in paradigm from a teacher-centred to a learner-centred model brought about further scrutiny of the traditional assessment and evaluation methods. It is therefore important to utilise trustwcrthy assessment and evaluation methods in clinical nursing education.

OSCE (Objective Structured Clinical Examination) as a method of clinical evaluation has dominated for years and has gained the status quo. It is, according to Harden \& Gleeson (in Nicol \& Freeth, 1998:602) the best known and most widely researched development in clinical competency assessment pioneered by the medical profession. Learners are expected to demonstrate their caring virtue and must therefore be able to define problems accurately, make the best choice from an array of possible alternative solutions, safely implement the care plans and evaluate the effectiveness of their actions. Learners need critical and reflective thinking skills to be evaluated in order to be safe and competent practitioners of the profession (Jenkins, 1985; Malek, 1986 and Mellish, Brink \& Paton, 1998). The question, however, is whether OSCE is effective in view of the expectations of the nursing/midwifery profession and the demands placed by the transformation towards competency-based nursing education and the evidenced-based nursing practice. Does OSCE measure what it is supposed to measure? Its validity is questionable (Gillings \& Davies 1998:8).

The assessment and evaluation of the learners' clinical competence traditionally takes place in the demonstration/practical rooms within colleges of nursing, mainly in the form of OSCE. This approach adds value to the traditional scientific authority and ensures adherence to well-established clinical protocols, routine practices and atomistic, specification assessment and evaluation systems characterized by a detailed list of skills (Nicol \& Freeth, 1998:601 and Halloway, 2000:2). Such an approach to education has proved to be inadequate (Halloway, 2000:4) and does not adequately equip graduates for a future holistic practice in any discipline (Wallace, Shorten, Crooke, McGurk \& Brewer, 1999:137). Concern has been expressed about the unrealistic and the artificial nature of the traditional system of clinical evaluation (Gillings \& Davies, 1998:8). Besides, state the authors, learners would pass the examination with high marks - up to $100 \%$, but would not make any difference in the clinical practice with regard to improvement on clinical reasoning skills. This problem raises much concern and the research question that arises is "What is the perception of clinical nurse educators with regard to the use of OSCE as a method of clinical evaluation of learners undergoing a four-year comprehensive diploma course in Gauteng Province?"

The purpose of this article is to explore and describe the per- ceptions of nurse educators with regard to the use of OSCE as a method of clinical evaluation of learners in Gauteng.

\section{Definition of Concepts}

\section{Nurse educator}

A person registered with SANC as a nurse educator, who acts as a facilitator of the learning process through education and training of nurses and midwives to provide diversified comprehensive health care within the National Health System in a variety of settings, within and outside hospitals. Facilitation is achieved through active involvement and participation of nurses/midwives to enable them to change, analyse and solve problems, to develop analytical, critical, reflective and creative thinking skills, to communicate effectively, to adopt an ethos of caring and to have a positive attitude towards learning which will inspire them to become lifelong learners (SANC, 1999:2)

\section{The learner}

A person undergoing a basic comprehensive diploma in nursing (general, psychiatric and community health) and midwifery registered with the South African Nursing Council. The learner is prepared to render beginning professional nursing. A practitioner and generalist nurse clinician and midwife is expected to practise professionally with independence in clinical decision-making and problem-solving, case management, community empowerment, supervision of other staff and efficient use of resources (SANC 1999: Document A, 2; Document B,1).

\section{Clinical assessment and evaluation methods}

Clinical assessment methods are methods that utilise multiple indicators and resources of evidence as a process of gathering information about the learners' progress. These methods involve a process of collecting, analysing and interpreting evidence in learning achievement. Evaluation is the process whereby information obtained through assessment is interpreted to make judgements about the learners' competence. It is a process of determining the merit, worth or value of a process or the product of that process (Mellish et al, 1998:224; Gravett. 2000; Van der Horst \& McDonald. 1997:169).

\section{OSCE: description}

OSCE is an acronym for Objective Structured Clinical Examination, which is popular as a means of summative (or final) evaluation for clinical competence at a particular stage of a course to decide on promotion to a further course of study, to complete a definite section of a course, or at the end of a course (Mellish et al, 1998:252). The basic format is that learners rotate among a number of stations spending a shorter period $(5$ or 10 minutes) at each, during which they must perform a particular clinical skill. Often, the required skill is set in the context to respond to a short, written scenario in the presence of a simulated patient. A learner's performance is assessed against a detailed checklist of the components of the skill. Some stations are manned, some are unmanned and some are resting stations provided in between. A bell-ringer is equipped with a second-hand watch to monitor and control time. The overall assessment is made by aggregating scores from the various stations (Nicol \& Freeth, 1998:602 and Mellish et al, 1998:252). 


\section{Research Design and Methods}

A qualitative, contextual, exploratory and descriptive research strategy was utilised (Mouton \& Marais 1994:43-44,51). Focus group interviews (Krueger 1994:6) were conducted in three nursing colleges affiliated to the Nursing Science Department at a university in Gauteng, to collect data from nurse educators who met the sample criteria for this research. The population consisted of nurse educators involved in a four-year comprehensive diploma course (general nursing, community health, psychiatry) and a midwife in the three nursing colleges affiliated to the Nursing Science Department at a university in Gauteng. The participants had to meet the sampling criteria based on five or more years of involvement with the learners' clinical evaluation using OSCE. Sampling was purposive in that all the participants volunteered with enthusiasm to take part in the research. There were six participants from two nursing colleges and eight participants from the third nursing college $(\mathrm{N}=20)$. Written permission was obtained from the partisipants as well as from the relevant Department of Health and the various Assistant Directors of Nursing Colleges to conduct the focus group interview using a tape recorder.

According to Krueger (1994:6), a focus group interview is defined as a carefully planned discussion conducted with seven to ten people. It is designed to obtain perceptions on a defined area of interest in a permissive, non-threatening environment. Focus group interviews were conducted in three nursing colleges on days that suited the colleges. An expert interviewer who holds a doctoral degree and is experienced in qualitative research was purposively selected to conduct the three focus group interviews, and the researcher collected field notes during the interview by noting group dynamics and interaction. The research question asked was:

What is your perception with regard to the use of OSCE as a method of clinical evaluation of learners following a basic nursing education programme?

The duration of the interviews was about one hour. The question was thoroughly dealt with until the perceptions were saturated. While tea was served to the participants, the researcher did a preliminary categorisation of the concepts, themes and patterns. A co-coder was purposively selected, based on extensive experience in qualitative research. The co-coder was given Tech's protocol for data analysis to be used. After one week, the researcher and the co-coder had a consensus discussion to arrive at common themes and sub-themes from the collected data. Follow-up interviews were conducted with two participants from each college to validate the findings.

Tesch's protocol (in Cresswell 1994:155) was used for the descriptive content analysis of the collected data, followed by a literature control. Lincoln and Guba's model (1985) was used to ensure trustworthiness throughout the study. Trustworthiness was ensured according to the four principles related to credibility, transferability, dependability and confirmability. Credibility was ensured through prolonged engagement since the researcher and the participants are experienced clinical nurse educators. The researcher took field notes and follow-up interviews were conducted to validate the categories deduced from the collected data. A literature control was conducted by using the findings of similar studies. To ensure transferability, the sampling method was purposive with no prior selection and a complete description of the design, methodology and literature control maintained transparency. A consensus discussion between the researcher and an independent coder as well as the description of the design and methodology ensured dependability. Confirmability was also ensured through the taking of field notes.

\section{Findings}

Five main categories pertaining to both positive and negative perceptions and their related themes emerged from the descriptive content analysis of data collected with regard to: aspects concerning administration, evaluators, learners, procedures/ instruments and evaluation. Both the positive and negative results will be discussed simultaneously and controlled by literature in the order displayed in table 1.

Participants were of the opinion that as much as OSCE has been a traditional and dogmatic method of clinical examination for learners, it also has positive aspects that contribute to effective teaching and learning. However, the negative perceptions raise much concern regarding the development of the clinical reasoning skills of the learners who are expected to make rational clinical decisions and solve problems. This concern poses a challenge to the nurse educators and all the stakeholders in the education and training of learners in nursing.

\section{Administration}

All the participants acknowledged the fact that good administration of OSCE can lead to effective learning. They indicated that the selection of an effective committee and a co-ordinator to plan the entire examination plays an integral part as evidenced by: "Every examination needs a committee and a leader to co-ordinate the planning, execution and control of the entire examination, or else there will be confusion throughout".

However, the participants felt that a well-organised OSCE could accommodate a large group of learners smoothly as cited: " $A n$ effective committee that plans well in advance can evaluate a large number of learners simultaneously and timeously without causing confusion".

Yet, on the negative aspect, most participants emphasised the fact that most of the time, the tutors are not clear about the principles guiding the management, execution, monitoring and evaluation of OSCE, as quoted: "It is a fact that most tutors are just followers in as far as the running of OSCE is concerned. We have not been adequately prepared about the management and execution of OSCE. We learn on the job". Some participants also stated: "Without the theoretical base, OSCE becomes a nightmare for both students and tutors, and this contributes to the lack of co-operation and a genuine commitment of tutors to the entire examination. Where there is lack of knowledge, negative attitudes and feelings build up".

Another aspect that was raised was the composition of the elected committee and co-ordinator. In this aspect, the participant stated: "The co-ordinator and the committee usually do not have expert clinical knowledge, skills and values resulting in the examination not being goal-directed" other partici- 
pants stated: "Without the expert knowledge and vision, OSCE is viewed as part and not a whole activity: It becomes difficult to handle a large group, the organisation of staff and resources, venues and time schedule become a confusion". At this point, the participants were demonstrating their anger and dissatisfaction. They were expressing themselves with emotions in order to make their point.

It must be realised that clinical assessment and evaluation are actually the 'life blood' of professional learning and must therefore be taken seriously (Gravett, 2000:2). Every clinical examination needs good administration with careful planning. The selection of a committee is mandatory. Mellish et al (1998:244,251) stated that all forms of assessment and evaluation require careful planning, with consultaticn, testing, a review of the previous examinations from time to time and alterations made according to the changing needs. The authors acknowledged the fact that assessing clinical competence is a difficult task, which is nevertheless absolutely vital. Collaborative consultation with other interdisciplinary health teams is essential for the evaluation to be holistic and goal-directed. Major and Pines (1999:122) assert that collaboration and information sharing plays an integral part in decision-making since the decisions made will influence the way things are done. The authors maintain that collaboration drives change. It allows teachers to engage, reflect and collaboratively agree on solutions to problems.

The following authors (in Major and Pines 1999:76,79) state categorically that the purpose of the examination committee and a co-ordinator is as follows: to clarify ideas and establish direction for the working group (Senge 1990), to foster commitment from individuals and groups (Conger 1992), to motivate others to achieve agreed-upon objectives (Conger 1992) and to develop a culture that reinforces individual performance (Cunningham \& Gresso 1993). The authors suggest that the selection of a committee should include people who are willing to create a bridge between the traditional leaders who must satisfy rigorous canons and norms, and others who respect the realities of clinical practice and honour service to the community.

The selection should include people who are willing to create an atmosphere of guidance, mentorship, facilitation, staff development and peer leadership. People who are open to learn new clinical skills, demonstrate respect for others, value a flattened hierarchy and committee, and who are open to the current wave of reform and restructuring that is challenging these traditional roles and recognise new forms of leadership are imperative. People who will look at life from a different angle Bennis (in Major \& Pines 1999:79) and make their colleagues do things they would not ordinarily do on their own to improve their quality of professional practise should be included (Wasky in Major \& Pines 1999:79). It is also imperative for the criteria against which the learners will be judged to be compiled by a group of experts most concerned with the technique. These criteria should be reviewed from time to time and revised as necessary (Mellish et al, 1998:248; Boud 1995; Van der Horst \& McDonald 1997).

The administrative aspect of the clinical assessment and evaluation is important and requires commitment and a mind-shift of the committee members from individual to participatory deci- sion-making. Solar and Conejeros (2000:8) assert that participative decision-making produces good quality, but warn that the practice of quality is not a straight line but a spiral Every new planning should generate a new process, but will have to start from the revision of previous assessment and evaluation experiences, followed by careful planning, performance, revision and readjustment proposals.

With reference to nurse educators' lack of expertise in OSCE, Major and Pines (1999:78) are of the opinion that it is no surprise that many teachers lack confidence in the ability to evaluate positively, and Mellish et al (1998:253) urge that the teacher training programme should prepare teacher learners to meet the needs of the community. Teachers need an ongoing update of clinical competence. They need enough support in order to play a meaningful role in clinical teaching. The authors encourage nurse educators to attend in-service education, or other updating offered in both the theoretical and clinical aspects of nursing as well as new advances in educational technology. Nurse educators are encouraged to undertake self-evaluation to identify their strengths and weaknesses.

A lack of human and material resources was perceived as a limitation of OSCE as this adds stress and strain to the tutors and learners. Going from one department to another requesting necessary equipment or seeking staff to be evaluators is rather absurd. Mellish et al (1998:254) argue that OSCE can be very frustrating and stressful for learners and examiners, and suggest therefore that in all evaluations, care should be taken to eliminate stress in learners as far as possible. Thoughtful planning and organisation of any assessment and evaluation are imperative (Mellish \& Johnston, 1986). In the same vein, Nicol and Freeth (1998:603) are of the same opinion that the traditional OSCE has severe limitations that have an impact on the assessment of clinical nursing skills. These entail limited time for each situation, handling large numbers of learners, small venues and lack of equipment. Gillings and Davies (1998:8) maintain that because of these constraints, vital aspects of clinical competence may be omitted, resulting in the credibility of OSCE as a method of clinical evaluation being questioned.

\section{Evaluators}

The participants, as evaluators themselves, expressed their genuine perspective in this regard. They indicated that OSCE encourages team spirit as they all actively participate in the preparing, executing and evaluating the examination as evidenced by the following citation: "OSCE actually fosters a collaborative and co-operative spirit amongst tutors. We work together and share ideas and therefore learn from each other." Furthermore, some participants indicated that OSCE improves their observation skills, as cited: "When you are an evaluator, you have to stay alert throughout, lest you miss out on some steps performed by the student. Your observation skills are sharpened."

Yet, on the negative aspect, the participants also provided their genuine perspective in this regard. They indicated that subjectivity, inconsistency and incompetence among tutors exist as quoted: "You sometimes become subjective since a student can impress you at face value and you just allocate high marks on impression. Sometimes you lose concentration and on 
realising that the student is already performing other steps, you simply tick in the middle to play it safe. Sometimes you are not sure about the performance of certain aspects of the procedure and you find yourself marking in the middle or lower simply because there is no time to verify with the other tutor." Participants also indicated that: "That is why you find that the two evaluators in the same station have a wide discrepancy in marks such as a $30 \%$ discrepancy. Many factors have an impact on the tutor's evaluation process".

Again, most of the participants expressed their frustration due to the lack of interaction and time to think during an evaluation, as cited: "It is frustrating to see the student performing in a certain way, but you cannot ask the reasoning behind her action because 'silence' is the order of the day".

The participants also expressed their concern about the use of professional nurses as evaluators in OSCE, as quoted: "The use of professional nurses in OSCE is minimal and this makes the sisters lose their credibility as having a role in clinical teaching". Compounding the problem is that: "Even when it is decided to involve the ward sisters, they are never briefed or prepared in the use of the instruments and how OSCE is run. The whole situation is frustrating".

The notion of OSCE encouraging active tutor participation, sharpening their observation skills and encouraging teamspirit is reiterated by Major and Pines $(1999: 78,122)$ who state that interactive collaboration and information-sharing play an integral part in decision-making as those decisions have an influence on the way things are done. They maintain that collaboration drives change, allows teachers to engage, reflects and collaboratively agrees on solutions to problems. It is important for tutors to develop a positive attitude, an attitude of receptivity, empathy and openness to sharing ideas with others in order to acquire knowledge. Team spirit or partnership in clinical assessment and evaluation involves all the stakeholders in the education and training of learners, such as, unit nurse managers, ward sisters, central sterilising department staff, infection control officers, clinical nurse educators, preceptors or mentors and learners. This integrated collaborative approach to clinical assessment and evaluation is in keeping with the contemporary requirements of the outcomes-based education and is greatly encouraged.

Concerning the problem of subjectivity, inconsistency and incompetence among some nurse educators, Boud (1995:169) has attributed these problems to systematic bias, which leads to giving higher and lower marks. Of concern is whether this is a conscious act or not. In this regard, the author states that the question of the reliability of the evaluators is subject to scrutiny (Andursyszn, 1990:411). Rowntree (in Boud, 1995:158) has identified the unreliability of teacher marking. Studies have demonstrated that there are discrepancies between evaluators, with the same evaluation overtime, even when there is apparent agreement of what is being assessed. They maintain that different perspectives can give rise to different interpretations and ideas about what is important, which may lead to lack of interrater reliability of evaluators.

Holzbach and Kegel-Flom (in Boud 1995:159) suggest the following considerations of how to improve maker reliability:
- $\quad$ Establish explicit criteria for satisfactory and unsatisfactory performance.

- Use scales in which the categories are unambiguously defined.

- Do not use scales that are more sensitive than the fineness of discrimination allows.

- Train evaluators by applying accepted criteria to typical examples of work to be evaluated and by resolving differences through discussions between evaluators to reach consensus on the interpretation of the criteria.

Ward sisters should not be excluded in this worthwhile exercise, but should be empowered with the necessary knowledge and skills of clinical assessment and evaluation.

\section{Learners}

Participants acknowledged the fact that OSCE contributes positively to learning and enhances the learners' confidence and self-esteem, as cited: "During OSCE students are actively involved and demonstrate confidence as they use all their senses to collect data and make quick decisions. Even a shy student who is an introvert plays her part that day".

The aspect on the validity of OSCE was raised and some participants felt that a well- planned OSCE could evaluate the cognitive, affective and psychomotor skills of the learner, but there was some debate on this issue, as cited: "IfOSCE is well planned, all the three domains, that is, the cognitive, affective and psychomotor skills can be evaluated, but the levels of the thinking skills are to be considered, especially the affective domain." On the other hand, participants stated categorically that some learners do not take OSCE seriously, as cited: "Some students do not take OSCE seriously and would actually joke about it. To them, clinical examination is not meaningful but rigid and suppressive to their individuality". Besides, stated some participants: "OSCE expects students to perform uniformly according to the checklist. It does not allow for creativity and flexibility of individual students. In a relaxed supporting environment, even a nervous student can perform to his or her maximum potential".

Participants further stated that: "There is no time for students to reflect on their experience. The scenarios written on little papers and instructions do not provide adequate information to make decisions. Whilst they still read the scenarios, the bell rings for them to start. The student then acts quickly like a robot without any thinking. It is crazy and very frustrating to both the student and the tutor".

Participant added: "Interpersonal skills and the affective component are not adequately evaluated as the whole exercise is sterile". What is even more frustrating to the learners is the use of their peer group as patients, as quoted: "The negative reaction of a student can be easily displayed especially if the 'said patient' is not her friend. It puts the student off completely".

To overcome some of the problems created by OSCE, Nicol and Freeth (1998:601) assert that the validity of an OSCE is reliant upon the quality of the problems posed at each station and, most importantly, the agreement of assessment checklists 


\begin{tabular}{|c|c|c|}
\hline CATEGORY & POSITIVE THEMES & NEGATIVE THEMES \\
\hline Administration & $\begin{array}{l}\text { 1. Effective committee and co-ordinator } \\
\text { ensure smooth running of the } \\
\text { examination. } \\
\text { 2. Large numbers of learners can be } \\
\text { evaluated simultaneously and } \\
\text { timeously. }\end{array}$ & $\begin{array}{l}\text { 1. Tutors not clear about the guiding } \\
\text { principles of OSCE. } \\
\text { 2. Planning is haphazard. } \\
\text { 3. Committee members lack expertise in } \\
\text { OSCE. } \\
\text { 4. Lack of human and material resources. } \\
\text { 5. Time constraint. }\end{array}$ \\
\hline Evaluators & $\begin{array}{l}\text { 1. Encourages team spirit. } \\
\text { 2. Improves observation skills of } \\
\text { evaluators. }\end{array}$ & $\begin{array}{l}\text { 1. Subjective, inconsistent and incompetent. } \\
\text { 2. There is no interrater reliability } \\
\text { 3. No interaction with learners } \\
\text { 4. Less involvement of ward sisters - if } \\
\text { involved, no debriefing in the use of } \\
\text { instrument. }\end{array}$ \\
\hline Learners & $\begin{array}{l}\text { 1. Active involvement using all senses. } \\
\text { 2. Evaluate the cognitive, affective and } \\
\text { psychomotor skills. }\end{array}$ & $\begin{array}{ll}\text { 1. } & \text { Some learners do not take OSCE } \\
\text { seriously. } \\
\text { 2. } \\
\text { 3. Principle of individuality not considered. } \\
\text { No time to reflect on their experiences. } \\
\text { Insufficient knowledge base acquired } \\
\text { from written scenarios - no time for } \\
\text { proper history taking. } \\
\text { 5. Interpersonal and affective skills are not } \\
\text { evaluated effectively. } \\
\text { 6se of peer group as patients has a } \\
\text { negative impact on learners' perform- } \\
\text { ance. } \\
\text { Learners become very nervous and feel } \\
\text { threatened. }\end{array}$ \\
\hline Procedures/ Instruments & $\begin{array}{l}\text { 1. Simulated procedures - patients lives } \\
\text { and their privacy is not at risk. } \\
\text { 2. Less threatening. } \\
\text { 3. Some stations do not require an } \\
\text { evaluator. }\end{array}$ & $\begin{array}{l}\text { 1. Simulated procedures are not realistic. } \\
\text { 2. Not holistic but atomistic and superficial. } \\
\text { 3. Certain procedures are not easy to } \\
\text { 4imulate. } \\
\text { 4. Manner of improvising is not realistic } \\
\text { 5. Ind is confusing. } \\
\text { 6. Criteria for evaluation and critical points } \\
\text { are not clearly defined. }\end{array}$ \\
\hline Evaluation & $\begin{array}{l}\text { 1. Feedback from learners is invaluable. } \\
\text { 2. More procedures can be evaluated. }\end{array}$ & $\begin{array}{l}\text { 1. No immediate feedback. } \\
\text { 2. Learners express their anger through } \\
\text { evaluation. }\end{array}$ \\
\hline
\end{tabular}

by means of a panel of expert opinions. Authentic problems are encouraged through which learners are given enough time to reflect and make their own interpretations and decisions. It is advisable rather to have less stations where learners would have time to apply their own clinical reasoning and prioritise actions appropriately in a realistic manner than to have many stations that encourage superficial thinking actions rushing to complete the procedure. In this way, the communication skills and the affective components could be evaluated adequately. The learners are advised to use the teacher as a resource person if necessary. This will, according to Nicol and Freeth (1998:603) reduce the nervousness and the feeling of being watched.
Fahy and Lumby (i Nicol and Freeth, 1998:603) assert that OSCE should aim to integrate and contextualise the skills, modify the number of stations and length of time at each station, some stations could take up to 45 minutes. This was found to improve the validity and reliability of the examination, to reduce learner stress and to encourage learners to reflect upon and evaluate their own experiences.

Concerning the use of the peer group as patients, Nicol and Freeth (1998:604) suggest that university staff or ex-nurses who do not make regular contact with the learners under examination could be used. This makes the assessment authen- 
tic by removing prior knowledge and expectations. Learners are not distracted by the 'simulated patients' having preconceived ideas about the behaviour of individual learners. The authors maintain that it is important for the simulated patients to be primed to ask questions that would enable the learners to demonstrate their communication and affective skills.

\section{Procedures/Instruments}

All the participants acknowledged the fact that since OSCE mostly involves simulated procedures, the patients' lives are not at risk, as cited: "OSCE is ideal because the lives of patients are not put at risk, their privacy is not invaded and dolls do not get tired. It is also less threatening and the inclusion of unmanned and resting stations is desirable to students".

On the other hand the participants expressed their dissatisfaction in that simulated procedures are unrealistic and not holistic. Certain procedures cannot be evaluated as it may be difficult to simulate them, as cited: "Simulated procedures are not realistic and holistic. Students cannot get the human feeling of the procedure. They perceive the procedure as parts and thus the holistic nature of the performance cannot be developed. Simulation can be confusing since it is done in an unrealistic manner, such as sterile packs are packed differently, yet when the procedure was demonstrated, correctly packed packs were used. This causes the student to be devastated and confused".

Again, participants indicated the problems of the evaluation instrument, as stated: "Evaluation instruments are not properly developed. They do not provide a wide range of evaluations especially when a checklist with YES or NO is used. The instrument does not allow for justification and reasoning. Instead, instruments are developed in such a way that a student with poor performance would get a high mark and a gifted student would have $+100 \%$ pass. Even the critical points are not clearly defined, they do not allow for creativity and are not realistic. Allocation of marks for these critical points is not consistent according to the weight of the item".

Nicol and Freeth (1998:604) assert that OSCE suffers from the characteristic problem of the quest for objectivity, which leads to the lengthy and atomistic specification of content and standards such as a 20 or more item checklist used for 5 minutes at single-task stations. The emphasis on measurable parts can miss the essence of the whole (Wolf 1993). There is much concern about the distorting effects of checklists, resulting in learners having a tendency to learn these skills in a fragmented way (Nicol and Freeth, 1998:458). The authors suggest the development of 'global rating' when the overall performance of learners at a station is graded on a scale with descriptors. It has been suggested that global rating should allow for the discriminating reasoning, which is thought to be the hallmark of clinical competence. The authors suggest the use of guided framework proposed by Benner (1984), which has been elaborated on to consider the attainment of specified learning outcomes with reference to standards of safety, accuracy, effectiveness and affective component (Parker 1995). To increase the validity and reliability of the examination, it is advisable to include self-evaluation of the learner during discussion with the assessor.

Mellish et al (1988:248) assert that provided that the learners are subjected to such 'proficiency' testing frequently and are judged by more than one person, rating scales can provide a very accurate picture of the learners' competency and other characteristics. Learners must be aware of the criteria against which they are being assessed. Critical points must be clearly described and the authors suggest that instead of using the concept critical, rather use safe patient care.

\section{Evaluation}

With reference to the evaluation of OSCE by the learners, the participants felt that it is an important aspect of the examination and allows for more learners to be evaluated simultaneously, as cited: "The feedback we get from students is invaluable because they indicate the strengths and weaknesses of the examination and also where improvement has to be made", and "OSCE can accommodate many students if well planned".

Yet, on the negative aspect, the participants stated: "Truly speaking, students wait for a long time before the results are published. Station and item analyses are not made. Moderation is not effective and even when they get results there is no positive feedback given".

With reference to the evaluation written by the learners immediately after OSCE, some participants stated that: "Some evaluations are positive but mostly students find this exercise a way of expressing their anger, and the comments can even be insulting at times".

On the whole, the participants felt that the evaluation was not done properly to benefit the learner and the tutor. It is noted that post-evaluation conferences held by both learners and evaluators to discuss the strengths and weaknesses of the examination and how to improve the standard are invaluable (Chabeli 1995). This notion is supported by Mellish et al (1998:248) and Nicol and Freeth (1998:605) who maintain that the learners' results should be discussed with them after completion of the evaluation as a learning process.

\section{Conclusion}

Participants perceived the use of OSCE as a method of clinical evaluation in both positive and negative ways. Five themes were identified as aspects concerning the administrative aspects; evaluators, learners; procedures/instruments and the evaluation of OSCE.

The positive aspects with regard to administration are that OSCE requires an effective committee and a co-ordinator to ensure smooth running of the entire examination. Of utmost importance is collaborative and co-operative planning, execution and control of the examination. Nurse educators need to be empowered with the necessary competencies in order to conduct OSCE successfully. Proper administration of OSCE would allow large numbers of learners to be evaluated simultaneously and timeously. On the other hand, poor and ineffective administration results in the lack of human and material resources as well as time constraints causing stress for both the learner and the evaluator. What compounds the problem is the committee members and evaluators who lack expertise and 
guiding principles for OSCE to be conducted effectively.

The positive perceptions about the evaluators are that OSCE encourages team spirit and improves the evaluator's observation skills. The negative perceptions indicated the subjective, inconsistent and incompetent tendencies of the evaluators. Lack of interrater reliability, lack of interaction with learners during the examination and less involvement of ward sisters in OSCE were also posed as negative.

The positive perceptions of the participants with regard to the learners are that OSCE encourages active involvement of learners by using all the senses. It also enables the evaluation of the cognitive, affective and psychomotor skills. The negative perceptions described are that some learners do not take OSCE seriously. Learners become nervous, especially when fellow learners are used as patients. The time provided for learners to reflect on the procedure in relation to previous experience is limited. The written scenarios provide insufficient information to enable the learner to analyse, interpret and reflect on the activity to be performed.

With regard to the procedures and instruments, the positive perceptions are that OSCE constitute mostly simulated procedures and are therefore less threatening to the learners, and the patients' lives and privacy are not at risk. Negative perceptions are that the simulated procedures are not realistic and holistic. Certain procedures are not easy to simulate since improvisation makes the procedures become unrealistic and meaningless, causing confusion for learners. Evaluation instruments and the criteria for evaluation are not well developed and they lack clarity.

The positive perceptions on the evaluation of OSCE are that the feedback from learners is invaluable. More procedures could be evaluated in a single examination. The negative aspects are that no immediate feedback is provided to the learners. There is no station and item analyses to determine the strengths and weaknesses of the stations or the items for future improvement. Some learners regard OSCE evaluation as an opportunity to express their anger and some comments could sometimes be insulting to the evaluators.

\section{Recommendations}

In the quest to improve clinical evaluation, nurse educators need to strive towards improving and turning the negative aspects into challenges, and strengthening the positive aspects of OSCE. It is, however, recommended that further research be undertaken to explore and describe the use of alternative, authentic methods of assessment and evaluation to measure the learners' comprehensive and holistic clinical competence. 
ANDRUSYSZYN, MA 1990: Faculty education: a closer look and peer evaluation. Nurse Education Today (10): 410 - 414.

BENNER, P 1984: From novice to expert: excellence and power in clinical nursing practice. Addison-Wesley: Menlo Park, CA.

BOUD, D 1995: Enhancing Learning through Self-assessment. London: Kogan Page Ltd.

CHABELI, MM 1995: Guidelines for Professional Nurses as Clinical Learning Facilitators. Unpublished dissertation for Master's Degree. Rand Afrikaans University.

CRESSWELL, JW 1994: Research Design: Qualitative and Quantitative Approach. London: Sage Publication.

GILLINGS, B \& DAVIES, C 1998: Evaluating Student Performance. Nursing Times Learning Curve 2(8) October 7: 8 - 15.

GRAVETT, S 2000: Assessment and Evaluation Methods OBE. Unpublished paper presented at Forum for University Departments of Nursing in South Africa (FUNDISA AGM) 26 - 27 May 2000.

HALLOWAY, W 2000: Professional Teaching Standards: Global Perspectives. Unpublished paper presented at the $20^{\text {th }}$ International Seminar for Teacher Education. Annapolis. Maryland, April 17-232000.

JENKINS HM 1985: Improving clinical decision-making in nursing. Journal of Nursing Education. 24:242 - 243.

KRUEGER, RA 1994: Focus Groups: a practical guide for applied research. London: Sage Publications.

LINCOLN, YS \& GUBA, EG 1985: Naturalistic Inquiry. London: Sage Publication.

MAJOR, C \& PINES, R 1999: Teaching to Learn. Washington DC: National Education Association.

MALEK, CJ 1986: A model for teaching critical thinking. Nurse Educator 11(6) 20 - 23.

MELLISH, JM; BRINK, HIL \& PATON, F 1998: Teaching and learning the practice of nursing. Johannesburg: Heinemann.

MELLISH, JM \& JOHNSTON, SU 1986: Evaluation in Clinical Nursing. Durban: Butterworths.

MOUTON, J \& MARAIS HC 1994: Basic concepts in the methodology of the Social Sciences. Pretoria HSRC Publishers.

NICOL, M \& FREETH, D 1998: Assessment of Clinical Skills: a new approach to an old problem. Nurse Education Today (18) $601-609$.

PARKER, P 1995: Continuous Clinical Assessment. Unpublished curriculum document. St. Bartholomew School of Nurs- ing and Midwifery. City University.

RAMSDEN, P 1992: Learning to teach in higher education. London: Routledge.

SOLAR, MI \& CONEJEROS, ML 2000: Demands on Professional Teacher Training for the new millennium. Paper presented at the $20^{\text {th }}$ International Seminar for Teacher Education, ISTE. Annapolis, Maryland, USA. 17 - 23 April

SOUTH AFRICAN NURSING COUNCIL 1999: Transformation of Nursing Education and Training in South Africa. Document $\mathrm{A}$ and $\mathrm{B}$.

SOUTHAFRICANQUALIFICATIONAUTHORITY ACTNO. 58 of 1997: Department of National Education. Pretoria: Government Printer.

VAN DER HORST, H \& McDONALD, R 1997: OutcomesBased Education. A Teacher's Manual. Pretoria: Kagiso.

WOLF, A 1993: Assessment issues and problems in a criterion-based system. London: Further Education Unit.

WALLACE, MC; SHORTEN, A; CROOKES,PA; McGURK, C \& BREWER, C 1999: Integrating information literacy into an undergraduate nursing programme. Nurse Education Today (19) $136-141$ 